\title{
Islamic Consolidation in Kazakhstan: Success Story and Challenges of the Future
}

\author{
Ario Bimo Utomo \\ UPNVeteran Jawa Timur
}

\begin{abstract}
This article attempts to explain the process of Islamic consolidation in Kazakhstan, a young Muslimmajority state in Central Asia, which became independent following the demise of the Soviet Union. This paper begins with a view that the demise of communism had opened a door for Islamin identity to reemerge. Unlike its turbulent regional neighbors, the reintroduction of Islam in Kazakhstan has virtually been quite stable. Therefore, it is interesting to examine why such occurence happen, making its success an interesting case to discuss. Using the consolidation and securitisation concept, this paper examines how the rise of Islam is facilitated after the demise of the Soviet Union. There are three findings observed by this paper regarding Islamic consolidation in Kazakhstan: first, as a background, Kazakhstan benefits from the assimilation of Islam with the local traditions; second, the paper finds that a bi-faceted stance toward Islam is another contributing factor; third, research shows that the state has been responsive enough by securitising Islamic radicalism as its agenda. Those findings are relevant in order to portray the current condition in Kazakhstan amidst the threat of Islamic radicalism. This paper concludes with giving some reflections on the future of Islam and the political stability in Kazakhstan.
\end{abstract}

\begin{abstract}
Abstrak
Artikel ini berupaya menjelaskan proses konsolidasi Islam di Kazakhstan, sebuah negara mayoritas Islam di Asia Tengah yang berdiri menyusul runtuhnya Uni Soviet. Makalah ini ebrangkat dari pandangan bahwa runtuhnya komunisme telah memberi jalan pada identitas Islam untuk muncul kembali. Namun demikian, berbeda dari negara-negara sekitarnya, kembalinya identitas Islam di Kazakhstan terlihat lebih stabil. Sehingga, menarik bagi kita untuk mengamati mengapa hal tersebut terjadi. Menggunakan konsep konsolidasi dan sekuritisasi, makalah ini mencoba melihat bagaimana Islam difasilitasi kembali setelah runtuhnya Uni Soviet. Ada tiga temuan makalah ini mengenai konsolidasi Islam di Kazakhstan: pertama, sebagai latar belakang, Kazakhstan diuntungkan oleh terasimilasinya nilai-nilai lokal dan Islam; kedua, sikap negara terhadap Islam yang memiliki dua wajah juga merupakan faktor penunjang lain; ketiga, penelitian menemukan bahwa negara telah cukup responsif dengan melakukan sekuritisasi terhadap isu Islam radikal.Temuan-temuan tersebut penting sebagai potret awal melihat kondisi Kazakhstan di tengah ancaman radikalisme Islam kontemporer. Menutup makalah ini, penulis menyajikan refleksi terhadap masa depan Islam dan stabilitas politik di Kazakhstan.
\end{abstract}

Keywords: Kazakhstan; Islam; consolidation

\section{Corresponding author}

Email : ariobimo.utomo@gmail.com 


\section{Introduction}

The fall of the Soviet Union in 1991 is widely considered as a game-changing moment as it has considerably altered the course of international affairs for some reasons. Not only has it brought new debates regarding the future of our international system, but more fundamentally, it gave birth to twelve new post-Soviet states in regions such as the Eastern Europe, Baltic States, and the Central Asia. With the demise of the Soviet Union as their parent state, those states were cursed by uncertainties relating to their political legitimacy, economic performance, and socio-cultural identities. Currently, after nearly 25 years, those states emerge with their different respective trajectories, where some become liberal democracies and some do not; some become wealthier whereas some remain stuck in the rooted poverty.

Among those post-Soviet regions, countries in Central Asia have their own distinctive features. The five "stans": Kazakhstan, Kyrgyzstan, Tajikistan, Turkmenistan, and Uzbekistan are the countries which constitute this region. I suggest that there are at least three reasons why the Central Asia is an interesting object of our contemporary scholarship. First, unlike the rest of the former Soviet Union, the states which constitute the area are predominantly Muslim and Turkic (with the exception of Tajikistan, which is predominantly Persian). Second, unlike the rest of the former Soviet Union states which quickly evolve into liberal democracies, the states in Central Asia remain notorious with the prevalence of authoritarianism (Diamond 2008, p.190). Acording to the Freedom House (2017), four out of five states in Central Asia are classified as "not free", namely Kazakhstan, Tajikistan, Turkmenistan, and Uzbekistan. The only outlier, Kyrgyzstan, was the only state which is now classified as a "partly free" state albeit only scoring 34 out of 100, indicating a borderline position within its "partly free" group (see Table I). Third, as the region is situated at the very core of the Eurasian continent, Central Asia has been a turbulent place where different identities collide, creating the possibility of fragility which the states need to cope with.

For the focus of this discussion, I am going to look deeper into the case of Kazakhstan. Among the five different countries in Central Asia, Kazakhstan stands out as the largest and the wealthiest country in the region. Culturally, Kazakhstan is the most diverse country in Central Asia where. On the other hand, this country has also shown a degree of success by becoming the most stable country in its region. In their latest release on the Fragile States Index, the Fund for Peace (2017) has announced that even though all the Central Asian states is grouped within the "warning" category, Kazakhstan scores the best in Central Asia with ranking 113 out of 178 countries in the list, with the highest ranking indicates the most fragile (see Table II).

\section{Table I}

Freedom Index (2017)

\begin{tabular}{|c|c|c|}
\hline Rank & Country Name & Score (1=worst, $\mathbf{1 0 0}=$ best) \\
\hline 1. & Kyrgyzstan & 37 \\
\hline 2. & Kazakhstan & 22 \\
\hline 3. & Tajikistan & 11 \\
\hline 4. & Turkmenistan & 4 \\
\hline 5. & Uzbekistan & 3 \\
\hline
\end{tabular}

Source: Freedom House

(https://freedomhouse.org/report/freedom-world/freedom-world-2017) 
Table II

Fragile States Index (2017)

\begin{tabular}{|c|c|c|}
\hline Rank & Country Name & Score $(\mathbf{1}=$ best, $\mathbf{1 2 0}=$ worst) \\
\hline 1. & Kazakhstan & 65.9 \\
\hline 2. & Turkmenistan & 74.4 \\
\hline 3. & Kyrgyzstan & 80.3 \\
\hline 4. & Tajikistan & 81.8 \\
\hline 5. & Uzbekistan & 81.5 \\
\hline
\end{tabular}

Source: Fund For Peace (http://fundforpeace.org/fsi/)

This paper is inspired by a big question: why are some Central Asian countries are stable, whereas some others do not? Some authors have provided several initial studies regarding the factors which contribute toward it in the Post-Soviet Central Asia, and all of them offers different answers toward it. For instance, Collins (2006) highlights how traditional leadership through clans constitute a strong force in Central Asian politics. Another one like Kubicek (1998) examines the authoritarianism aspect of the region, and how the lack of democratic experience correlates toward the stability of the region. On the other hand, Cummings (2012) also mentions the aspect of civic and Islamic identity. From those literatures, the author concludes that there are several patterns of governance that is apparent: (1) the region is a region in transition which is still in search of its suitable formula of governance; (2) Central Asia and Islam are inseparable entities which define each other despite the decades of Soviet influence; and (3) democracy is virtually inapplicable in the region, and authoritarianisms are widespread throughout its constituent countries.

This paper attempts to highlight an important facet. To begin with, this paper regards that Islam is a strong power which resurged following the demise of the communist state. Second, from the two tables above, we can examine that Kazakhstan is the most stable among other post-Soviet states in Central Asia. Therefore, I am trying to link the way Islam contributes toward the current considerable stability of Kazakhstan. In this case, we are going to specify our highlight toward the process of how Islam is reintroduced and consolidated in the country.

This paper shall begin with clarifying some terms regarding the political consolidation and its practice in the nondemocratic regime types. Going onward, we shall outline how Islam re-emerges as an important feature in the Kazakhstani society following the fall of the Soviet Union. Later on, this paper will discuss how Islam has been successfully consolidated in the current political system of Kazakhstan without necessarily evolving into a conflicting power against the mainstream nationbuilding narratives. Lastly, we conclude this paper by discussing current trends and the lessons learned for the future.

\section{Political Consolidation}

The fall of the Soviet Union was arguably one of the most shocking phenomena to ever happen in the modern era. As for its constituent republics, that event had opened a new chapter where they now had to survive amidst all uncertainties caused by their newly-earned independence. Consequently, cementing legitimacy is among the main priorities of those post-Soviet states before stepping any further into the international realm.

The Weberian conception of the state stipulates that legitimacy is an integral factor in constituting what a good state is. Weber (1978, p.31) argues that legitimacy ensures a more stable basis of obedience. Without such obedience as an important feature, the new states would find it harder to implement policies. On the other hand, White agrees by saying that "all regimes, from naked 
tyrannies to pluralistic democracies, seek to legitimate themselves" (p.463). However, establishing legitimacy is a tricky business as states need to thoughtfully craft their political measures in order to ensure that their claims toward legitimacy would not result in civil resistance. This need to create a legitimate but stable government - particularly in the new states - translates into an imperative to consolidate the differing powers within the state.

Brooker (2013) states that there are two approaches of consolidation, particularly in new nondemocratic regimes, in order to secure their power. First, the new regime "claims to be legitimate" in order to ensure that the society accepts its legitimacy, thus easing the new regime to perform further actions. He adds some explanatory points regarding this approach. First, new regimes can claim their legitimacy through new constitutions, aiming to legitimise the regime through a superficially democratic manner. Second, the new regime can also directly claim their legitimacy by propagating "patriotic claims" which says that their new regime is a necessary response to the worse possible outcomes such as separation, civil war, or revolution (p.109). Once the first stage has been fulfilled, another approach which can be done by the regime is to "strengthen its control over society and state machinery". This second approach can be translated as an alternative move should the people perceive that such claims to legitimacy in the first approach are weak (p.107).

However, while the aforementioned mechanisms are sufficient to establish the internal legitimacy, I argue that they do not offer strong solutions to combat the perceived dangers from outside. Therefore, the newly-established regimes need to identify the external forces of change which can possibly disrupt the process of state-building. I suggest that securitization is another important feature in this process of political consolidation. According to its framework which has been neatly described by Waever (2004), securitization itself is a political move. It offers a contextbased approach which lets a certain phenomenon to be responded in a specific way. In other words, an issue is not of a security concern when it is not going through a process of "being securitised" (Waever, 2004, p.13). We can employ this reading to put a basic assumption that Islamic revival—as a specific phenomenon - was also going through a securitisation process in order to be consolidated in Kazakhstan's political realm.

Within the next sections of this essay, I am going to explain the brief history of Islam in Kazakhstan, its revival, and the rationale to consolidate it following the country's independence.

\section{Islam in Kazakhstan:A Brief Overview}

Islam is the most practiced religion in Kazakhstan. According to the 2009 census conducted by the Kazakhstani Government, the Muslim population of Kazakhstan reached $70.2 \%$ of the total population. On the other hand, Christianity is practiced by approximately $20 \%$ of the population (Smailov, 2011, p.24). Most Kazakhstani Muslims belong to the Turkic ethnic groups such as the Kazakhs, Uzbeks, and Uighurs. On the other hand, Christianity is mainly practiced by the Slavic ethnic groups such as the Russians, Ukrainians, and the Belarusians.

Historically, Islam arrived in the Central Asian region shortly after the death of the Prophet Muhammad. However, Islam did not quickly spread to the area which we know as the modern Kazakhstan until the $9^{\text {th }}$ century. Marshallsay (2009) writes that there were two stages of Islamisation in this country. The first one occurred on the $9^{\text {th }}$ to the $10^{\text {th }}$ century where the Arab conquerors captured Southern Kazakhstan and converted the local populace. The second wave was done between the $13^{\text {th }}$ century until the $19^{\text {th }}$ century. However, Islam had never positioned itself as a strong force in Kazakhstan, mainly due to two reasons: first, the nomadic culture of the Kazakh people had made it difficult for the Islamic propagators to establish sedentary religious facilities such as mosques and madrasas. Second, when the Bolsheviks took the force in the Kazakhstani area, the Soviet regime limited the practice of Islam into their own, state-sanctioned interpretation. On the 
contrary, the more observant religious activities are deemed as "extreme", thus disconnecting the Kazakhstani Muslims from the mainstream version of Islam. Moreover, the Soviet regime imposed the nationalism policy where Islam is linked with the national identity instead of with the religion's canonical practices, reducing it from into a mere national identifier where being Kazakh equals to being a Muslim (Omelicheva, 2011, pp.245-246).

Even though the Soviet Union and its state atheism had considerably repressed the activities of Islam in Kazakhstan, the non-ritual aspects of Islam have always been rooted deeply in its society. Although the Kazakhstani people do not necessarily translate their religious identity into doing the mainstream tenets of Islam (such as praying five times, attending mosques, refraining from eating pork and drinking alcohol, etc.), the Kazakhs show no problem in identifying themselves as Muslims to distinguish them from the Slavic peoples which are predominantly Christians (Gleason, 1997, p.42). In their everyday life, the Kazakhstani people perform Islam with some syncretic values from their ancient beliefs. However, it is also fallacious to assume that Islam is only a nominal identity in Kazakhstan, as it resonates with the local tradition of the people. Rasanayagam (2007) finds that Islam is compatible with the Central Asian society because it has several familiar practices such as "shrine visitations and celebration of life-cycle events" which reflect the spirituality of the local people (p.159).

The practice of Islam was revived some years prior to Kazakhstan's independence, it was when the Gorbachev's regime executed the glasnost policy, marking the twilight era of the Soviet Union. During this era, Islam gained more portion in the public life such as through the creation of the Islamic muftiate and by translating the Quran into the Kazakh language (Marshallsay, 2009, p.8). However, the revival of Islam was still under the control of the strong Soviet governance. However, when Kazakhstan became an independent country, there had been some degree of fear that the identities which were repressed during the Soviet years-including Islam-would rise into a resurging force which could destabilize the newly-independent state. In his article, Gunn pinpoints the Soviet invasion of Afghanistan in 1979 as one possible event which can fuel the revival of the political Islam in the region. This is a plausible geopolitical argument. With the Soviet Union no longer in place, Islamist groups in Central Asia could gain this momentum to spread their influence even further, particularly toward the less-stable areas. In his famous concept of the "clash of civilizations", Huntington writes that Central Asia is a region which falls to the sphere of the "Islamic civilization", one among the major civilizations of the world (p.25). Therefore, when Central Asia had cut its ties with the Russians (the Orthodox civilization, according to Huntington), it is understandable that this region could be "the next battleground" of the world (Rashid p.4).

\section{Islam in Modern Kazakhstan}

Since its independence in 1992, Kazakhstan has been witnessing an increasing religious trend. Eldebay notes this increase from several aspects, such as the increasing number of mosques (2,500 now versus 63 during the Soviet period), the growing number of Islamic schools, the increase of religious marriage ceremonies, as well as the growing number of hajj pilgrims (pp.123-4). Besides of such activities, Nursultan Nazarbayev, the first and the only president of Kazakhstan, also shows a personality shift which is friendlier toward Islam. At the beginning of his reign, he showed his symbolic stance to facilitate the revival of Islam by doing Islamic activities such as performing the hajj, building new mosques, and registering Kazakhstan as the member of the Organisation of the Islamic Conference (OIC) in 1995-thus shedding his former image as an atheistic communistregime apparatus (Marshallsay p.10). 
"The position of Islam in family matters also grows stronger. Celebrations of Islamic traditions become an integral part of everyday life of the Kazakhs. Most Kazakhs consider themselves Muslims and celebrate at least some part of the rites and rituals. That concerns the Friday Namaz in the Mosque, religious holidays (Oraza, Qurban ait), the ritual of circumcision (Sunnat/Sundet), the obituary-obsequies rituals and marriage rituals. Growing importance of the religious holidays is stressed by the fact that children born on those days get names like Aisha, Islam, Ramasan, Medina, Oras" (Eldebay 2012, p.124)

However, we should also note that not only did the fall of the Soviet regime has given Kazakhstan a chance to re-embrace its Islamic values. On the other hand, the losing attachment from its parent state has left a void in Kazakhstani ideological box, making it a contested field for other states to spread their influences. Aydingun (2010) states that following the independence of Kazakhstan, some Islamic states such as Saudi Arabia, Turkey, and Pakistan are "attempting to introduce their own versions of Islam" (p.73). Those countries have notably contributed toward the revival of Islamic activities by establishing state-sponsored schools and mosques.

In response to this revival of Islamic activities, the Kazakhstani government has been showing a dual-faced stance. Generally, they treat Islam both as an advantage and as a disadvantage. On one hand, they acknowledge the importance of Islam as something which gives a distinctive color toward the Kazakhstani society - thus it cannot be easily separated from the state. Yet, on the other hand, Kazakhstan also perceive the revival of Islam as a power which can challenge the government if it is not being managed correctly. In general, the first "face" is shown toward the more cultural version of Islam, an interpretation which had been already rooted in the Kazakhstani society. On the other hand, the second "face" is a response toward the more political form of Islam which the government perceives as a threat toward the new regime.

To examine how the state approaches to consolidate Islam, we can use several lenses. First, we can see it through the aspect of the law. In the 1995 constitution, or more precisely, through the Article 1, Kazakhstan stipulates that the country is built upon the characters of a "democratic, secular, legal, and social state". This emphasis on secularism signifies that the revival of religious activities does not mean a condition which favors one particular religion — or in this case, Islam, as the majority religion. However, the government has also been very cautious in order not to continue the Soviet-era narrative that religion has no place in the society. Again, in the Article 14, Kazakhstan provides a constitutional declaration that "no one shall be subject to any discrimination for reasons of origin, social, property status, occupation, sex, race, nationality, language, attitude towards religion, convictions, place of residence or any other circumstances". This legal statement makes Kazakhstan the only state not to give Islam any official status amongst the post-Soviet Central Asian states, thus denying any assumption that Islam would be established as the state ideology following the independence of Kazakhstan. As Laruelle (2015) says, this stance is also apparent in Nazarbayev's speech, where he has been more frequently using "religion" or "faith" as the substitute terms for "Islam" (p.5).

Besides assertively campaigning for secularism, it is apparent that Kazakhstan decides to continue the consolidating mechanism which was done in the Soviet era, indicating that Kazakhstan remains extremely careful in managing the resurging Islamic identity. Kazakhstan creates several bodies to regulate the practice of Islam, for instance, the country retains the muftiate DUMK (Spiritual Board for the Muslims in Kazakhstan) as the representative of the Kazakhstani Muslim in the absence of any Islamic political parties, which are not allowed to be established in Kazakhstan. One notable role of this body regulates the speech for the local Friday sermons. This notion recirculates the "state-sanctioned religion" policy which was done by the former Soviet regime. 
"When Nazarbayev established the Muftiate of Kazakhstan, he chose Ratbek Nisanbayev to be its first leader or mufti. Nisanbayev agreed that bringing Islam into politics would be harmful to both the nation and to the practice of the faith within it. He publically and repeatedly stated that any Islamist political party in Kazakhstan would create a 'breach of peace.'” (Walters, 2017)

On a personal level, Nazarbayev also shows an ambivalence stance toward Islam. President Nazarbayev has repeatedly tried to establish an identity that the "Kazakh version" of Islam is a moderate Sunni one, finding its foundations from the Hanafi school whose flexible interpretations "allowed the incorporation of pre-Islamic traditions and offered a relatively flexible framework of practice to believers" (Aydingun p.71). Having done so, Nazarbayev creates a clear demarcation line which separates the Kazakhstani Islam and the more conservative Wahhabism which rejects virtually all the traditional rites.

Applying Brooker's conceptual framework in place, this case study has shown that both the "claims of legitimacy" and "strengthening control over the society and the state machinery" have been taking place. According to this concept of political consolidation, Kazakhstan's government have been comprehensive enough in consolidating Islam. However, we need to understand that this success is not without any context. We can also argue that this success in the political consolidation is more determined by the illiteracy of the local populace about the mainstream Islam (Yemelianova p.294). However, it still does not deny the apparent tendency that Islam has been well-consolidated in the internal sphere of Kazakhstan.

Next, we shall examine the securitization dimension of the Kazakhstani government in facing the Islamic revival. Omelicheva examines that there are two greater narratives which the government use. The first narrative was used during the 1990's when Kazakhstan was still a newborn country. In this era, the Kazakhstani government circulated a narrative that the country was immune to the Islamists threats, creating an image of a strong state which attempted to discourage the radicals. However, during the 2000's until now, the narrative shifts by acknowledging that terrorism is the common enemy. If we are to contextualize it with the global trend, this narrative is relatable with the 11 September incident in the United States, where terrorism-particularly from the Islamist groups - rise as the new force in the global constellation (p.249). Moreover, when its neighbors have increasingly become the breeding grounds for terror groups, Kazakhstan could no longer be complacent about its safety. The second narrative signifies Kazahstan's attempt to securitize Islam as the political issue, a deeper part of the consolidation.

Nazarbayev's regime has apparently continued the Soviet-era policies by repressing any "parallel" Islamic practice which deviates from the "official" Kazakhstani version. Earlier this year, the government outlined some measures to "rehabilitate and de-radicalize" those who have been convicted of terror charges, indicating a "zero-tolerance" attitude to radicalism (Bogatik). In July, Kazakhstan passed a law amendment allowing the authorities to strip the citizenship of their citizens who are convicted of terrorism. Accordingly, Kazakhstan embraces a stance where they create their own version of the "state-sanctioned Islam" to avoid other extreme interpretations to emerge.

Nevertheless, such measures do not necessarily met without resistance. Albeit restricted, Islamist groups are staunch oppositions of the Nazarbayev governance. One group which is quite significant is the underground Hizbut Tahrir

\section{Future trends in Kazakhstan: How would it look like?}

Currently, Islam has considerably become a consolidated power within the Kazakhstani society. The state shows a consistent effort in demarcating Islam as a private matter and Islam as a political ideology. Kazakhstan has successfully managed the revival of its Islamic identity 
without necessarily resorting to excessive repression toward the Islamic identities or by completely succumbing to the Islamists.

However, we have to take an important note that from our previous explanations, it is apparent that Kazakhstan does not only benefit from the assimilation between Islam and local practice. Besides that, it owes the assertive leadership of Nursultan Nazarbayev as another contributing factor in balancing Islam and the state. The task would be even more complex when President Nazarbayev steps down as the leader. To a certain degree, political turbulence would be inevitable, and the balance of power in the Kazakhstani politics could fluctuate. Therefore, it is crucial that Kazakhstan should always position its counter-terrorism and deradicalization policies as a major priority if the country wants to retain its image as a stable Muslim-majority country. In the post-Nazarbayev Kazakhstan, those efforts should also be continued despite the possible fluctuations in the future political environment. In a bigger scale, is also preferable if the country can successfully retain its identity which conjoins faith and nationalism as a unifier (Utomo, 2017).

Islamic terror-wise, Kazakhstan has shown that the country is relatively safe from it by ranking 94 out of 130 countries in the Global Terrorism Index (2016), indicating a low level of terror. When we look at the Table III, Kazakhstan remains second to Uzbekistan, but if we take a look back at the Table II, we can see that Kazakhstan is much more a stable country compared to Uzbekistan. This signifies that the situation in Kazakhstan is accumulatively more preferable compared to its neighbors in the Central Asian region.

Table III

Global Terror Index (2017)

\begin{tabular}{|c|c|c|}
\hline Rank & Country Name & Score $(0=$ safest, $10=$ worst $)$ \\
\hline 1. & Uzbekistan & 0.154 \\
\hline 2. & Kazakhstan & 0.934 \\
\hline 3. & Kyrgyzstan & 1.445 \\
\hline 4. & Tajikistan & 3.086 \\
\hline 5. & Turkmenistan & N/A \\
\hline
\end{tabular}

Yet, it is not safe to assume that Kazakhstan would be completely immune from the threat of radical Islam. In 2016, the country experienced two attacks in major cities Aktobe and Almaty. On the other hand, the National Security Committee of Kazakhstan has also reported that the state has arrested 182 defendants on terrorism charges. Additionally, threats can also come from outside, particularly from other Central Asian countries such as Uzbekistan, Kyrgyzstan, Tajikistan, even China through its Uighur minority. The rise of globalization has opened a channel for external forces to infiltrate every aspect of our daily lives, including radical groups. Therefore, as the most influential country in the region, the leadership of Kazakhstan is essential for the greater good of the region in combating Islamic radicalism, and ensuring that peaceful Islamic values can be consolidated in post-Soviet Central Asia. As Rapoport (2006) says in his article, this world is currently experiencing the fourth wave of terrorism, a surge of terrorism which is mainly motivated by religious motives (p.61). However, I would also add that this fourth wave is getting more complex as the increasing use of information technology has made radical groups more unpredictable. Besides that, the world is experiencing the rise of ISIS-led Islamic terrorism which is more transnational in nature, making the counter-terrorism measures even more complex. In order to keep its stability, Kazakhstan should 
also cope with this issue. The looming challenge for Kazakhstan, therefore, is to consolidate Islam amidst the shifting global trend of radicalism. Whoever the future leader will be, Kazakhstan need to take the leadership in Central Asia and work together with its neighbours in order to contain the terror threat from spreading any further into the region.

\section{Conclusion}

From the discussion which we have covered beforehand, we observe that there are several factors which account for the success of the Islamic consolidation in Kazakhstan.

First, from the historical perspective, Kazakhstan benefits from the practice of Islam which has been successfully assimilated with the local traditions. The interpretation of Islam which was brought to Kazakhstan was incorporated with the traditional religious system which features mystical aspects. This, to some extent, has established Islam as an identity which cannot be separated from the Kazakhstani society.

Second, the Kazakhstani has been responsive enough to claim its legitimacy by doing a bi-faceted approach to Islam. On one hand, when the Soviet regime had ended, the government responded quickly by stipulating the state as a secular regime through its constitution. However, on the other hand, Kazakhstan also acknowledges the importance of creating its "own interpretation of Islam" by allowing the once-banned Islamic activities to re-emerge.

Next, securitization is another aspect which we should not neglect in this Islamic consolidation. The danger of transnational radical Islamic movements has moved Kazakhstan to position Islam as another issue to be securitized. Albeit much criticised, Nazarbayev's strong position against the radical groups has successfully made Kazakhstan a relatively stable country in Central Asia.

I acknowledge that this paper can only highlight a side of the complex reality of Islam in Kazakhstan. On the other hand, it only tries to assume that Islam plays a significant role in the stabilisation of Kazakhstan. Therefore, I hope that this paper can open up a further discussion about the future of Islamic consolidation in Kazakhstan. While the present looks promising for now, the post-Nazarbayev regime should ensure that the current strong consolidation would not result in resistance once Nazarbayev is no longer the leader. Establishing legitimacy by increasing the quality of democracy can be an alternative to be considered, so that Kazakhstan can be an exemplary case that Islam, modernisation, democracy, and stability can always go hand in hand. 


\section{References}

Aydıngün, Ayşegül. (2010) "Islam as a Symbolic Element of National Identity Used by the Nationalist Ideology in the Nation and State Building Process in Post-soviet Kazakhstan." Journal for the Study of Religions and Ideologies 6.17 (2010): 69-83.

Bogatik, Alexander. (2017) "Kazakhstan Calls for Zero-Tolerance of Radicalism." Central Asia News. <http://central.asia-news.com/en_GB/articles/cnmi_ca/features/2017/02/13/ feature-02>

Brooker, Paul. (2013). Non-democratic regimes. London: Palgrave Macmillan.

Collins, K. (2002). Clans, pacts, and politics in Central Asia. Journal of democracy, 13(3), 137-152.

Cummings, S. N. (2013). Understanding Central Asia: politics and contested transformations. Routledge.

Diamond, Larry. (2008) The spirit of democracy: The struggle to build free societies throughout the world. London: Macmillan.

Eldebay, Saniya. (2012). “Traditional Kazakh Culture and Islam”. International Journal of Business and Social Science 3(11): 122-133.

Freedom House (2017). Populists and Autocrats: The Dual Threat to Global Democracy. <https:// freedomhouse.org/report/freedom-world/freedom-world-2017>

Fund for Peace (2017). Country Dashboard. <http://fundforpeace.org/fsi/>

Gleason, Gregory. (1997). "Prospects for Kazakhstan’s Asian Liberalism,." Democratization 5(3): 376-385.

Gunn, T. Jeremy. (2003). "Shaping an Islamic identity: religion, Islamism, and the state in Central Asia." Sociology of Religion 64(3): 389-410.

Huntington, Samuel P. (1993). "The clash of civilizations?." Foreign affairs: 22-49.

Institute for Economics and Peace. (2016). Global Terrorism Index 2016: Measuring and Understanding the Impact of Terrorism. New York: Institute for Economics and Peace.

Kubicek, P. (1998). Authoritarianism in Central Asia: curse or cure?. Third World Quarterly, 19(1), 29-43.

Laruelle, Marlene. (2015) "The three discursive paradigms of state identity in Kazakhstan:

Kazakhness, Kazakhstanness, and transnationalism." Nationalism and Identity Construction in Central Asia: Dimensions, Dynamics, and Directions: 1-20.

Marshallsay, Zaniah. (2009). "The state and Islam in Kazakhstan and Tajikistan-managing religion in a secular environment." (2009): 1-15.

Omelicheva, Mariya Y. (2011). "Islam in Kazakhstan: a survey of contemporary trends and sources of securitization." Central Asian Survey 30(2): 243-256.

Rapoport, David C., ed. (2006) Terrorism: The fourth or religious wave (Vol. 4). Taylor \& Francis.

Rasanayagam, Johan. (2007) Book review of Islam after Communism: Religion and Politics in Central Asia. Cambridge: Cambridge University Press.

Rashid, Ahmed. (2002). "Jihad: the rise of militant Islam in Central Asia." New Haven.

Smailov, A., ed. (2011). Results of the 2009 National Population Census of the Republic of Kazakhstan: Analytical Report. https://www.liportal.de/fileadmin/user_upload/oeffentlich/ Kasachstan/40_gesellschaft/Kaz2009_Analytical_report.pdf. Astana: The Agency on Statistics of the Republic of Kazakhstan

Utomo, Ario Bimo. (2017). "Radicalism and the Challenge of Stability in Post Nazarbayev Kazakhstan”. Center for Security and Research. <https://crssblog.com/2017/08/15/ radicalism-and-the-challenge-of-stability-in-post-nazarbayev-kazakhstan/> 
Wæver, Ole. (2004). Aberystwyth, Paris, Copenhagen. New'schools' in security theory and their origins between core and periphery. In annual meeting of the International Studies Association, Montreal (pp. 17-20).

Walters, Alex. (2017) "Islam in Kazakhstan: Modern and Moderate". EdgeKZ. <http://www.edgekz. com/islam-kazakhstan-modern-moderate/>

Weber, Max. (1978) Economy and society: An outline of interpretive sociology. Vol. 1. Univ of California Press.

White, Stephen. (1986) "Economic performance and communist legitimacy." World Politics 38(3): 462-482.

Yemelianova, Galina M. (2014) "Islam, national identity and politics in contemporary Kazakhstan." Asian Ethnicity 15(3): 286-301. 